\title{
Analisis Hukum Acara Dalam Pelayanan Terpadu Sidang Keliling Pada Pengadilan Agama Gunung Sugih
}

\author{
Atika $^{1}$, I Ketut Seregig ${ }^{2}$, Melisa Safitri ${ }^{3}$ \\ 1,2,3Fakultas Hukum Universitas Bandar Lampung, Indonesia \\ Email konfirmasi: atikasurii05@gmail.com
}

\begin{abstract}
ABSTRAK
Dalam mencari keadilan pasti dibutuhkan suatu badan peradilan yang dapat memutuskan perkara yang sedang digugat/dimohonkan tentu putusan yang didapat akan kuat jika dihasilkan dari badan resmi berupa badan peradilan yang dinanunggi oleh mahkahmah agung seperti halnya pengadilan agama yang menyelesaikan perkara perdata terhadap individu dan individu lain, namun pada kenyataannya sering kali dijumpai masyarakat tidak dapat mengakses kedalam pengadilan dikarenakan jarak yang jauh atau ongkos biaya transportasi yang cukup mahal menjadi masyarakat enggan untuk melaksanakan sidang secara resmi sehingga mereka lebih memutuskan untuk menyelesaikan secara musyawarah, dengan adanya permasalah ini mahkamah agung mengeluarkan suatu sistem yang berbeda dalam melaksanakan sidang secara keliling atau langsung mendatangi masyarakat yang mencari keadilan namun dengan biaya yang tidak cukup besar dan persidangan yang cepat.
\end{abstract}

Kata Kunci : Hukum Acara, Pelayanan, Sidang Keliling

\section{Pendahuluan}

Indonesia merupakan negara yang berlandaskan akan Hukum. Hal ini sesuai dengan apa yang termaktub dalam Undang-Undang Dasar Negara Republik Indonesia 1945 atau yang disingkat dengan UUDNRI 1945 dalam Pasal 1 ayat (3) yang menyatakan bahwa Negara Indonesia adalah negara Hukum, dalam pelaksanaan penyelenggaraan hukum maka harus adanya badan pengadilan di Indonesia, seperti Mahkamah Konstitusi dan Mahkamah Agung beserta badanbadan peradilan yang ada dibawah, Pengertian pengadilan secara khusus, yaitu suatu lembaga tempat mengadili atau menyelesaikan sengketa hukum dalam rangka kekuasaan kehakiman yang mempunyai kekuasaan absolute dan relative sesuai peraturan perundang-undangan. Dalam bahasa Arab disebut al-Mahkamah. (Sulaikhan Lubi, 2005, hlm. 3)

Berdasarkan hukum positive yang berlaku di Indonesia jelas bahwa ada empat badan peradilan yang dinaunggi oleh Mahkamah Agung, diantaranya yaitu peradilan umum, Peradilan Agama, peradilan militer, dan peradilan tata usaha Negara, Salah satu badan peradilan yang penting ialah peradilan agama, peradilan 
agama sebagai salah satu menyelesaikan perkara dalam bidang keperdataan yang menyangkut masyarakat yang beragama islam, dalam proses berperkara dalam peradilan agama.

Peradilan agama yang merupakan pengadilan khusus, Pengadilan Agama memiliki beberapa tugas yang diberikan kewenangan tertentu memeriksa, memutus dan menyelesaikan suatu perkara-perkara di tingkat pertama antara orang-orang yang beragam Islam dalam bidang: perkawinan, kewarisan, wasiat, hibah, wakaf, zakat, infaq, shodaqoh, dan ekonomi syariah.(Musthofa Sy. 2008, hlm. 61-62)

Sama seperti halnya peradilan yang lain membutuhkan ongkos berperkara, namun sering dijumpai masalah keuangan untuk bisa mengakses berperkara di Pengadilan Agama yang berkaitan dengan biaya perkara dan ongkos serta ransportasi yang lumyan mahal menjadikan Mahkamah Agung memberikan perhatian besar untuk dapat terselenggaranya dengan menerapkan sidang keliling dan pembebasan biaya perkara dengan proses prodeo.

Ini bisa dilihat dengan keluarnya surat edaran Mahkamah Agung Nomor 10 Tahun 2010 tentang Pedoman Pemberian Bantuan Hukum, baik di lingkungan Peradilan Umum dan di lingkungan Peradilan Agama dan selanjutnyan diubah kedalam peraturan mahkamah agung Nomor 1 Tahun 2014 tentang Pedoman Pemberian Layanan Hukum Bagi Masyarkat Tidak Mampu Di Pengadilan,

Dengan adanya peraturan tersebut memberikan efek yang positif dalam hal mekanisme pemberian layanan pembebasan biaya perkara atau bisa disebut dengan perkara prodeo yang mengacu kepada surat edaran mahkamah agung Nomor 10 Tahun 2010 tentang Pedoman Pemberian Bantuan Hukum,

Dalam memberikan bantuan hukum kepada masyarakat yang ingin berperkara secara prodeo yang pertama harus memiliki Surat Keterangan Tidak Mampu atau yang disingkat denga SKTM dari kepala desa setempat, lurah, atau pejabat yang setingkat.

Selanjutnya Masyarakat juga dapat membawa Kartu Jaminan Kesehatan Masyarakat atau yang disingkat dengan Jamkesmas atau sejenisnya umtuk bukti bahwa yang bersangkutan tidak mampu membayar biaya perkara,

Selanjutnya surat-surat tersebut harus diajukan bersama-sama dengan pengajuan surat gugatan di pengadilan saat akan memulai mendaftarkan sebuah perkara. Selanjutnya majelis Hakim akan meninjau dan menangani perkara yang bersangkutan untuk membuat putusan sela untuk dapat memutuskan apakah layak gugatan/permohonan tersebut dapat dilaksanakan secara prodeo, jika gugatan/permohonan tersebut diterima maka berperkara secara prodeo pun akan diterima namun jika ditolak maka penggugat/pemohon diwajibkan untuk membayar panjar biaya perkara dalam jangka waktu 14 hari setelah adanya penjatuhan putusan sela, jika penggugat/pemohon tidak mampu maka guggatan tersebut akan dicoret. 
Jika melihat dalam peraturan mahkamah agung Nomor 1 Tahun 2014 tentang Pedoman Pemberian Layanan Hukum Bagi Masyarkat Tidak Mampu Di Pengadilan, pemberian pembebasan biaya dalam berperkara sebenarnya masyarakat tidak harus terlebih dahulu melaksanakan sidang dan menunggu putusan sela untuk mengetahui apakah permohonannya dapat untuk mendapatkan pembebasan biaya perkara.

\section{Metode Penelitian}

Penelitian ini menggunakan pendekatan yang bersifat Pendekatan yuridis normatif ialah dengan menggunakan perundang-undangan yang terkait, Pendekatan empiris yaitu dilakukan dengan melihat secara langsug terkait objek penelitian dengan cara observasi dan wawancara.

\section{Pembahasan/hasil}

\section{A. Pelaksanaan Sidang Keliling yang dilaksanakan oleh Pengadilan Agama Gunung Sugih Lampung Tengah}

Dalam menyelesaikan suatu perkara dipersidangan baik pedata maupun pidana harus berdasarkan pada prinsip asas cepat, sederhana dan biaya ringan. Supaya setiap masyarakat dapat mendapat keadilan dalam menyelesaikan perkaranya, Pengadilan Agama sebagai salah satu pelaksana kekuasaan keHakiman melaksanakan suatu sistem persidang yang disebut dengan sidang keliling sebagai bentuk upaya melayani masyarakat dalam pelayanan bagi para masyarakat yang mencari keadilan dinegeri ini.

Menurut Wahyu Widiana, sidang keliling ditujukan untuk memberikan kepastian hukum kepada masyarakat di bidang hukum keluarga baik status pernikahan, perceraian maupun status anak.( Tri aji pamungkas, 2019, hlm. 9)

Pada prinsip dan tujuannya sidang keliling memiliki prinsip pokok yakni sidang secara sederhana cepat dan biaya ringan (M. Yahya Harahap. 2001, hlm. 56)

selain itu tujuan lain diadakannya sidang keliling untuk mempermudah akses bagi masyarakatb yang berada diperkampungan atau domisilnya tidak memiliki kantor peradilan agama, maka sidang keliling sebagai solusi untuk menyelesaiakn suatu perkara pada sidang diperadilan agama.

Sidang keliling sangat membantu masyarakat dalam memperjuangkan keadilan yang hakiki, disaat masyarakat membutuhkan penegak hukum untuk menyelesaikan perkara yang membutuhkan putusan untuk memperkuat kekuatan hukumnya, akan tetapi terhalang oleh hambatan-hambatan yang mungkin tidak mampu dijangkau oleh mereka, maka disaat itulah proses sidang keliling sangat membantu dan dibutuhkan. Berikut adalah manfaat yang didapat dengan adanya proses sidang keliling: Lokasi sidang lebih dekat dengan tempat tinggal yang 
mengajukan perkara. Biaya transportasi lebih ringan. Lebih menghemat waktu.( Zaki Hidayatullah. 2016, hlm. 217).

Berdasarkan hasil wawancara penulis dengan Pak Rifqi M. Khairumman, S.Sy selaku Hakim pada Pengadilan Agama Gunung Sugih Kelas 1B Lampung Tengah ia menggatakan bahwa sidang keliling adalah salah satu dari bentuk pengabdian kepada masyarakat dengan melaksanakan pelayanan kepada masyarakat, Lanjutnya sidang keliling merupakan proses persidangan yang dilakukan diluar gedung ataupun diluar ruang pengadilan dan bekerja sama dengan aparat desa menggunakan gedung-gedung desa ataupun kelurahan yang sudah disediakan sebelumnya, Pada prosesya sidang keliling tentu saja sama dalam proses pelaksanaan sidang di pengadilan, tetap adanya Hakim, panitera dan lain-lain, hanya saja tempat beracara nya yang berbeda. adapun perkara yang dapat diajukan untuk sidang keliling yaitu : Itsbat nikah atau pencatatan pernikahan yang belum tercatat pada Kantor Urusan Agama, Cerai gugat atau suatu gugatan perceraian yang diajukan oleh seorang istri, Cerai talak atau permohonan cerai yangg diajukan oleh seorang suami, Penggabungan perkara itsbat dan cerai talak, Hak asuh terhadap anak, Penetapan ahli waris, Permohonan wali adhal.

Pengadilan pada umumnya melaksanakan sidang keliling di balai desa, kantor kecamatan, atau tempat fasilitas umum yang mudah diakses oleh masyarakat yang tinggal jauh dari kantor pengadilan. Langkah-langkah mengajukan perkara pada sidang keliling tahap pertama : Mencari informasi tentang sidang keliling melalui website pengadilan, kantor kecamatan atau kantor desa kemudian Melihat jadwal kapan akan dilaksanakan Waktu sidang keliling, Tempat sidang keliling, Biaya Perkara dan bagaimana Tata cara dalam mengajukan perkara melalui sidang keliling, tahap kedua, Pada tahap ini masyarakat haru melengkapi dokumendokumen yang diperlukan sebelumnya yaitu : Membuat pengajuan guggatan, Melengkapi dokumen yang disyaratkan, Membayar panjar biaya perkara Bagi yang tidak mampu dapat mengajukan prodeo, Pemohon/penggugat membawa 2 orang saksi, Menyerahkan semua persyaratan yang sudah lengkap tersebut diatas meja pengadilan, selanjutnya pada Langkah ketiga yaitu Mengikuti Proses Persidangan dengan Datang ketempat sidang keliling yang disiapkan sebelumnya dan Membawa Dua orang saksi dan mengikuti dengan tertib dan berpakaian sopan kemudian Setelah diputus salinan putusan bisa diambil di Pengadilan atau ditempat sidang keliling.

Bila melihat kedalam Peraturan Mahkamah Agung Nomor 1 Tahun 2014 tentang Pedoman Layanan Hukum Bagi Masyarakat Tidak Mampu di Pengadilan yang ddapat menerima pembebasann biaya perkara ialah setiap orang yang dikatakan tidak mampu secara ekonomi dan membutuhkan bantuan dari pengadilan berupa pembebasan ongkos perkara pada prinsipnya pemberian layanan 
pembebasan biaya perkara dapat dilaksanakan sesuai kebutuhan disetiap tahun anggaran.

sidang keliling sangatlah membantu untuk meringankan para pihak berperkara tetapi masih pada batasan yang normal, belum memberikan dampak yang signifikan terutama dalam pembiayaan biaya perkara. Khusus untuk perkara cerai, biaya perkaranya merupakan biaya yang harus ditanggung oleh para penggugat/pemohon untuk pembiayaannya, sementara jika melihat kondisi perkara sidang keliling untuk wilayah Pengadilan Agama Gunung Sugih masih lebih banyak perkara gugatan cerai dengan jumlah sebanyak 16 perkara untuk tahun 2021, artinya bahwa yang harus menanggung biaya perkara adalah pihak penggugat dalam hal ini adalah istri yang berdasarkan hasil penelitian di lapangan menunjukan lebih banyak para pihaknya yang berasal dari keluarga yang kurang mampu dan layak untuk mendapatkan pembebasan biaya perkara.

Hadirnya proses sidang keliling yang bertujuan untuk memudahkan para pihak dalam berperkara di Pengadilan Agama khususnya di Pengadilan Agama Gunung Sugih sebagai salah satu bukti dari komitmen yang dijalankan oleh badan peradilan untuk memberikan layanan Hukum kepada masyarakat yang membutuhkan.

Bahwa berdasarkan jabaran diatas pelaksanaan sidang keliling pada Pengadilan Gunung Sugih yakni sidang yang dilaksanakan di luar gedung pengadilan yang layanannya terutama ditujukan bagi warga negara yang mengalami hambatan geografis dan ekonomis untuk datang ke kantor pengadilan karena alasan jarak, transportasi dan biaya, pelaksanaan sidang keliling sama saja dengan pelaksanaan sidang di pengadilan, tetap adanya hakim, panitera dan lain-lain, hanya saja tempat beracara nya yang berbeda.

\section{B. Tinjauan Hukum Islam terhadap pelaksanaan Sidang Keliling di Pengadilan Agama Gunung Sugih Lampung Tengah}

Terkait mengenai Hukum tentu kita akan terlintas dalam pikiran kita bahwa hukum merupakan peraturan-peraturan atau seperangkat norma yang dibentuk oleh badan resmi yang bertujuan akan hal mengatur tingkah laku masyarakat dalam suatu negara, baik peraturan atau norma itu berupa kenyataan yang tumbuh dan berkembang dalam masyarakat, suatu hukum yang berkembang dan di hormati oleh masyarakat indonesia ialah terhadap hukum Islam yang diperuntukan untuk masyarakat yang beragama islam dapat dikatakan hukum islam bersumber pada $\mathrm{Al}$ Qur,an maupun hadist, selain itu, tujuan lain diberlakukan Hukum Islam adalah sebagai upaya untuk kemaslahatan hidup manusia, secara rohani maupun jasmani, individual dan sosial.

Hukum islam juga mengatur pelaksanaan sidang keliling yang berdampak 
positif salah satunya dapat memberikan keadilan kepada masyarakat luas. dengan membantu masyarakat yang memiliki jarak rumah yang jauh dari kantor persidangan, biaya transportasi dan mesyarakat yang tidak memiliki kendaraan menjadikan persidangan lebih cepat dan sederhana, dengan datang pihak penggadilan langsung ke lokasi akan mempermudah proses pelaksanaan pemeriksaan yang lebih cepat karena hanya membutuhkan pelaksanaan sidang paling lama dalam empat kali sidang.

Tinjauan Hukum Islam terhadap pelaksanaan sidang keliling di Pengadilan Agama Gunung Sugih adalah upaya untuk dapat mewujudkan suatu kemaslahatan kepada kehidupam masyarakat yang lebih luas melalui ketentuan hukum, Dalam hukum Islam sangat mendukung tegaknya sebuah keadilan, karena keadilan sebagai salah satu akhlak dalam Islam yang harus diamalkan dalam semua aspek kehidupan.

Berdasarkan hasil wawancara penulis dengan pak Rifqi M. Khairumman, S.Sy selaku Hakim pada Pengadilan Agama Gunung Sugih Kelas 1B Lampung Tengah bahwa selama melaksanakan sidang keliling kadangkala dalam hal menghadapi masyarakat awam seringkali ada pertentangan mengenai dilaksanakannya sidang keliling karena menurut masyarakat namun hal tersebut hanya terkait mengenai perkara yang menyangkut perceraian selain itu dengan adanya sidang keliling ini menurut masyarakat salah satu hal yang memudahkan proses perceraian, akan tetapi dengan usaha menjelaskan bahwa demi tercapainya keadilan bagi seluruh rakyat Indonesia masyarakat dapat menerima adanya sidang keliling.

Sidang keliling sangat membatu masyarakat terutama masyarakat yang tidak mampu, tinggal jauh dari dari kantor pengadilan dengan adanya sidang keliling Masyarakat mendapatkan akses yang lebih mudah untuk menyelesaikan suatu perkara hukum, Pelaksanaan sidang keliling di Pengadilan Agama Gunung Sugih memudahkan masyarakat dalam mencari keadilan untuk dapat memperoleh keadilan dampak dari itu akan memberikan kemaslahatan dan kemudahan kepada masyarakat luas, diharapkan pelaksanaan sidang keliling atau sidang di luar gedung pengadilan akan terus dan tetap diprogramkan oleh Mahkamah Agung Republik Indonesia.

Bahwa berdasarkan uraian diatas dapat disimpulkan bahwa Pandangan Hukum Islam pada pelaksanaan sidang keliling di Pengadilan Agama Gunung Sugih merupakan suatu cara ntuk dapat memudahkan masyarakat seta melindunggi kemaslahatan yang diberikan kepada masyarakat sesuai konsep yang disebut dengan maslahah mursalah yaitu mengambil suatu untuk dari adanya manfaat dan membuang kemadharatan untuk menjaga tujuan-tujuan syara.

Eksistensi peradilan agama di indonesia harus menjadi salah satu yang terdepan dalam melindunggi hak-hak masyarakat terutama mereka yang terabaikan dan tidak tersentuh keadilan, dengan ini peradilan agama dapat menjadi jalan bagi 
masyarakat yang lemah dan buta untuk mendapatkan akses keadilan, dimana setiap masyarakat bisa merasakan keadilan.( Wahyu Widiana. 2012, hlm 23-27).

\section{KESIMPULAN}

Berdasarkan hasil penelitian dan pembahasan mengenai Analisis Hukum Acara Dalam Pelayanan Terpadu Sidang Keliling (Studi Pada Pengadilan Agama Gunung Sugih) maka penulis dapat mengambil kesimpulan sebagai berikut:

Secara umum dapat diartikan bahwa sidang keliling adalah sidang pengadilan yang dilaksanakan di luar gedung pengadilan yang layanannya terutama ditujukan bagi warga negara yang mengalami hambatan geografis dan ekonomis untuk datang ke kantor pengadilan karena alasan jarak, transportasi dan biaya. Pengadilan biasanya melaksanakan sidang keliling di balai desa, kantor kecamatan, atau tempat fasilitas umum yang mudah dijangkau oleh masyarakat yang tinggal jauh dari kantor pengadilan, yang sebelum penentuan tempat telah dilakukan survey oleh Jurusita. Pelaksanaan beracara sidang keliling sama saja dengan proses beracara di Pengadilan Agama pada umumnya, namun yang membedakan hanya sidang keliling beracaranya diluar pengadilan.

Bahwa berdasarkan jabaran Dalam Pandangan Hukum Islam pelaksanaan sidang keliling di Pengadilan Agama Gunung Sugih merupakan bentuk kemudahan atau kemaslahatan yang diberikan kepada masyarakat sesuai dengan konsep maslahah mursalah yaitu mengambil manfaat dan menolak kemadharatan dalam rangka memelihara tujuan-tujuan syara. Jika ditinjau dari segi maqasid syari" ah maka adanya sidang keliling memudahkan masyarakat pencari keadilan untuk memperoleh keadilan guna memelihara agama, jiwa, akal, harta, dan keturunan. Karena memberikan kemaslahatan dan kemudahan kepada masyarakat.

\section{DAFTAR PUSTAKA}

M. Yahya Harahap. 2001. Kedudukan Kewenangan dan Acara Peradilan Agama, Jakarta, Sinar Grafika.

Musthofa Sy (2008), Pengangkatan Anak Kewenangan Peradilan Agama. Jakarta, Kencana Prenada Group.

Sulaikhan Lubis (2005), Hukum Acara Perdata Peradilan Agama di Indonesia., Jakarta, Prenada Media.

Tri aji pamungkas. 2019. Kepastian Hukum Penyelesaian Perkara Perceraian Melalui Sidang Keliling Pengadilan Agama Argamakmur Dalam Yurisdiksi Kabupaten Mukomuko, Tesis Pascasarjana Institut Agama Islam Negeri, Bengkulu.

Wahyu Widiana. 2012. Peran Peradilan Agama Dalam Pembangunan Acces To Justice Di Indonesia, (Direktorat jendral Badan Peradilan Agama Mahkamah Agung Republik Indonesia. 
Zaki Hidayatullah. 2016 Efektivitas Sidang Keliling Pengadilan Agama Sampit Dalam Penyelesaian Perkara Hukum Keluarga, Volume 12, Nomor 2. 